\title{
SMART-СИСТЕМА ДИСТАНЦЙНОГО СУПРОВОДЖЕННЯ РЕАБІЛІТАЦЙНИХ ЗАХОДІВ: ФОРМАЛЬНА МОДЕЛЬ, ПРОГРАМНА РЕАЛІЗАЦІЯ ТА МЕТОДОЛОГІЯ ЗАСТОСУВАННЯ
}

\author{
Величко В. Ю',., Малахов К. С. ${ }^{2}$, Палагін О. В. ${ }^{3}$, Семикопна Т. В. ${ }^{4}$, Щуров О. С. ${ }^{3}$ \\ Інститут кібернетики імені В.М. Глушкова НАН Украӥни, м. Київ, Украӥна

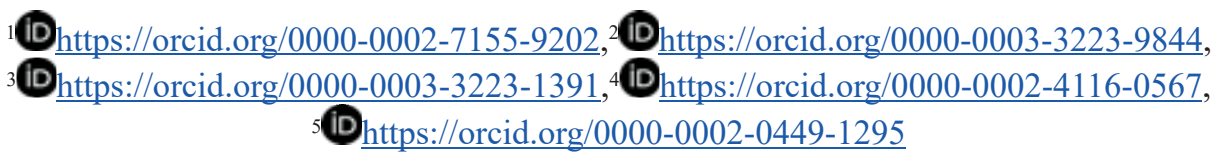

Для кореспонденції: Палагін Олександр Васильович, Академік Національної академії наук України, доктор технічних наук, профресор, Заслужений винахідник України заступник директора з наукової роботи Інституту кібернетики ім. В.М. Глушкова НАН України, завідувач відділу мікропроцесорної техніки № 205, Київ, 03187 , Україна, Проспект Академіка Глушкова, 40; e-mail: palagin_a@ukr.net; тел.: +38 (044) 5263348.

\begin{abstract}
Методологія реабілітаційних заходів в умовах пандемії має ряд суттєвих особливостей, пов'язаних 3 непередбаченістю і високою швидкістю виникнення проблем високої складності, обмеженістю спілкування між реабілітологом і пацієнтом, необхідністю високої реактивності прийняття рішень і їх відповідністю, масштабністю процесу, і пов'язаною 3 нею необхідністю використання масштабованих операційних засобів тощо. Одним з ефективних рішень в наданні медичної реабілітаційної допомоги є дистанційна пацієнт-центрична реабілітація, яка потребує опline-засобів теледіагностики, телеметрії і втручання з орієнтацією на можливості пацієнта, розвинутої Internet-взаємодії, інтелектуальних інформаційних технологій і сервісів, ефективних методів когнітивної підтримки в системі "Реабілітолог - Пацієнт - Мультидисииплінарна команда”, статистичної обробки великих об'ємів інформації тощо. Звідси поряд $з$ традиційними засобами реабілітації у складі системи Трансдисциплінарної інтелектуальної інформаційно-аналітичної системи супроводження процесів реабілітації при пандемії TISP з'явилася Smart-система телемедичного супроводження реабілітаційних заходів. В поєднанні з інтелектуальними дистанційними засобами біологічного зворотнього зв' язку і ефективними мініатюрними приладами теледіагностики, телеметрії і відновлення такі системи мають великі перспективи, про що свідчить також і світовий досвід. Мета дослідження полягала в розробці формальної моделі, програмної реалізації та методологічних засад застосування сервісів дистанційної пацієнтцентричної Smart-системи надання медичної реабілітаційної допомоги пацієнтам при пандемії, зокрема, нової коронавірусної хвороби COVID-19. Світове сучасне та загальноприйняте визначення поняття Телереабілітація або Е-реабілітація - це комплекс реабілітаційних вправ і навчальних програм, які надаються пацієнту дистанційно за допомогою телекомунікаційних комп’ютерних технологій переважно на амбулаторному етапі лікування. Бурхливий розвиток телереабілітації у світі та набуття цим напрямком медицини трансдисциплінарних зв'язків з різноманітними предметними галузями, що виходять за рамки сучасної парадигми Е-здоров'я, призвів до появи найсучаснішого різновиду реабілітації-Гібридна Е-реабілітація. Цей різновид Е-реабілітаціі складається з ряду наступних фундаментальних методів, підходів та технологій: телекомунікаційні технології, телеметрія, вбудовані системи та мініатюрні “розумні” прилади для носіння, біологічний зворотний зв”язок, віртуальні особисті помічники, методи, технології та програмні застосунки на основі штучного інтелекту для обробки великих даних. Розроблено формальну модель, програмну реалізацію та методологічні засади застосування сервісів (UkrVectōrēs та vHealth) дистанційної пацієнт-центричної Smart-системи надання медичної реабілітаційної допомоги пацієнтам при пандемії, зокрема, нової коронавірусної хвороби COVID-19.
\end{abstract}

Ключові слова: міжнародна класифікація функиіонування, реабілітація, пацієнт-центрична реабілітація, мультидисциплінарна команда, електронна бібліотека, обробка природної мови, штучний інтелект, інтелектуальні інформачійні технології.

Вступ. Методологія реабілітаційних заходів в умовах пандемії має ряд суттєвих особливостей, пов'язаних 3 непередбаченістю i високою швидкістю виникнення (на відміну від звичайної ситуації) проблем високої складності, обмеженістю спілкування між реабілітологом i пацієнтом, необхідністю високої реактивності прийняття рішень і їх відповідністю, масштабністю процесу, i пов'язаною 3 нею необхідністю використання масштабованих операційних засобів тощо.
Одним 3 ефективних рішень в наданні медичної реабілітаційної допомоги $є$ дистанційна пацієнтцентрична реабілітація, яка потребує onlineзасобів теледіагностики, телеметрії і втручання 3 орієнтацією на можливості пацієнта, розвинутої Internet-взаємодії, інтелектуальних інформаційних технологій і сервісів, ефективних методів когнітивної підтримки в системі "Реабілітолог - Пацієнт Мультидисциплінарна команда”, статистичної 
обробки великих об'ємів інформації (зокрема даних анкетування та телеметріі) з виділенням достовірних знань тощо. Звідси поряд 3 традиційними засобами реабілітації в процесі реалізації проєкту "Трансдисииплінарна інтелектуальна інформаційноаналітична система супроводження процесів реабілітації при пандемії (TISP)" [1], що переміг у конкурсі "Наука для безпеки людини та суспільства" Національного фонду досліджень України (НФДУ) [2] й отримав грантове фінансування, у складі системи TISP, з'явилася Smart-система телемедичного супроводження реабілітаційних заходів. В поєднанні 3 інтелектуальними дистанційними засобами біологічного зворотнього зв'язку [3] і ефективними мініатюрними приладами (англ. Embedded systems, Wearable devices) теледіагностики $[1,4]$, телеметрії і відновлення такі системи мають великі перспективи, про що свідчить також і світовий досвід.

Smart-система телемедичного супроводження реабілітаційних заходів - це комплексна, інтегрована, пацієнт-центрична інформаційна підсистема TISP надання медичної допомоги, вирішення різних клініко-організаційних та науководослідних задач у галузі реабілітаційної медицини (консультації; дистанційний нагляд і супроводження реабілітаційних процесів та заходів; виявлення, класифікація, прогнозування та вивчення знань; дослідження та огляд нових предметних галузей), 3 використанням засобів дистанційного зв'язку, елементів технологій штучного інтелекту, зокрема, онтологічного інжинірингу [5 - 8] та машинного навчання [9].

Мета дослідження полягала в розробці формальної моделі, програмної реалізації та методологічних засад застосування сервісів дистанційної пацієнтцентричної Smart-системи надання медичної реабілітаційної допомоги пацієнтам при пандемії, зокрема, нової коронавірусної хвороби COVID-19.

Матеріали і методи. Реабілітація людей що одужали від COVID-19, $є$ безумовно вкрай важливою соціальною проблемою. Цей факт вже добре розуміється міжнародною лікарською спільнотою. У той самий час доступність реабілітаційних заходів у різних країнах дуже різна. В країнах з розвинутою страховою медициною процес реабілітації в відповідних спеціалізованих центрах доступний багатьом. На жаль, в Україні ситуація інша - потреби пацієнтів в амбулаторних реабілітаційних послугах набагато перевищують наявні ресурси, що вимагає пошуку альтернативних рішень і підключення сучасних i передових технологій для підтримки пацієнтів. Тому $є$ велика потреба у використанні нового сучасного напрямку відновлювальної медицини - телереабілітації.

Світове сучасне та загальноприйняте визначення поняття Телереабілітація або Е-реабілітаціія (англ. E-rehabilitation) [4] - це комплекс реабілітаційних вправ і навчальних програм, які надаються пацієнту дистанційно за допомогою телекомунікаційних комп'ютерних технологій переважно на амбулаторному етапі лікування. Сенс цього сучасного напряму у тому, що пацієнт самостійно, як правило у домашніх умовах, виконує програми відновлювального лікування на амбулаторному етапі під дистанційним контролем і керівництвом лікаря спеціаліста. Телереабілітація має супроводжуватися відповідним програмним забезпеченням, яке дозволяє спеціалісту 3 реабілітації, що спостерігає пацієнта в стаціонарі, швидко скласти індивідуальний комплекс вправ для самостійних занять в відеоформаті. Даний комплекс має коригуватися в залежності від динаміки відновлення. Таким чином пацієнти мають змогу продовжувати структуровану програму домашньої реабілітації, розроблену на стаціонарному етапі. Пацієнти отримують зворотний зв'язок від вже знайомих фахівців, відзначаються результати, досягнуті за минулий період, ставляться нові, актуальні для пацієнта завдання, здійснюється об'єктивний контроль відповідних функцій, Все це, безумовно, покращує і підтримує мотивацію пацієнта та забезпечує значно більшу ефективність амбулаторного етапу реабілітації.

Телереабілітація $\epsilon$ втіленням відразу декількох сучасних технологічних трендів. Поперше, телереабілітація неможлива без власне телекомунікаційних технологій. По-друге, вона потребує застосування спеціалізованих для реабілітації медичних інформаційних систем. Ці системи потрібні, як для адміністрування пацієнтів, так, і це є найголовніше, для створення низки реабілітаційних документів відповідно до структури реабілітаційного циклу, наприклад, індивідуального реабілітаційного плану, категоріального профілю, реабілітаційного прогнозу тощо. По-третє, важливою частиною телереабілітаційних технологій $є$ функціональне оцінювання стану пацієнтів в домашніх умовах 3 використанням мініатюрних приладів та сучасних алгоритмів оцінювання даних у відповідності 3 тенденцією, яка англійською називається pointof-care testing, що у вільному перекладі означає медичний тест, який здійснюється безпосередньо в місці знаходження пацієнта, поза офісом лікаря. Нарешті, телереабілітація неможлива без активного залучення пацієнта до процесу прийняття рішень щодо його діагностики та лікування. Це є однією 3 основних тенденцій сучасної медицини, яка була підтримана в тому числі і на рівні законодавчих ініціатив в системі охорони здоров'я України.

Бурхливий розвиток телереабілітації у світі та набуття цим напрямком медицини трансдисциплінарних зв'язків 3 різноманітними предметними галузями, що виходять за рамки сучасної парадигми Е-здоров'я (англ. E-health), призвів до появи найсучаснішого різновиду реабілітації - Гібридна Е-реабілітація (англ. Hybrid E-rehabilitation) [10]. 


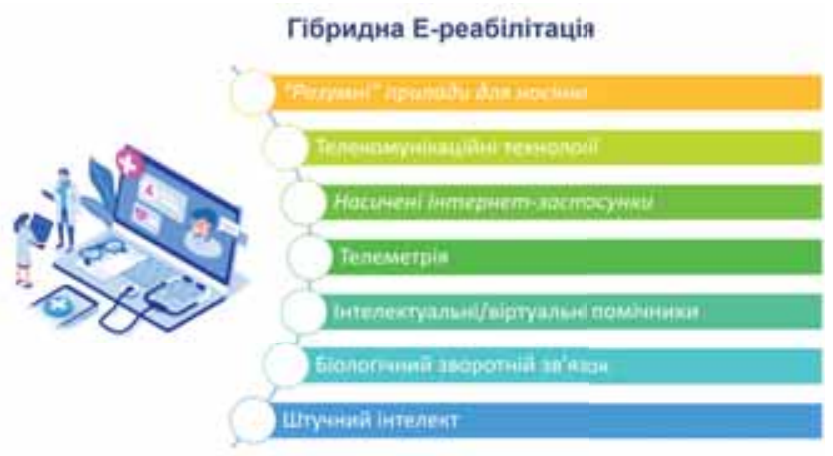

Рис. 1. Фундаментальні методи, підходи та технології Гібридної Е-реабілітації.

Гібридна Е-реабілітація складається 3 ряду наступних фундаментальних методів, підходів та технологій (рис. 1):

- Телекомунікаційні технології - надання реабілітаційних послуг через телекомунікаційні мережі та Інтернет. Крім того, це дозволяє пацієнтам дистанційно взаємодіяти 3 провайдерами та може використовуватися як для оцінки пацієнтів, так і для проведення терапії.

- Насичені Інтернет-застосунки (англ. Rich Internet application). Перш за все це медичні інформаційні системи (МIC). МIC - це всебічна, інтегрована інформаційна система, призначена для управління всіма аспектами роботи медичної установи (зокрема, поліклініки, лікарні або реабілітаційного центру), такими, як медичні, адміністративні, фінансові та юридичні питання 3 відповідною обробкою/обміном даних (зокрема, 3 реєстрами центральної бази даних електронної системи охорони здоров'я України [11]).

- Телеметрія - сукупність методів, підходів та технологій, що дають змогу проводити дистанційне вимірювання, збір, передачу та обробку інформації про показники діяльності (фізіологічні параметри) організму пацієнта (зокрема, при виконанні реабілітаційного комплексу вправ та заходів в реальному часі).

- Вбудовані системи (англ. Embedded systems) та мініатюрні “розумні" прилади для носіння (англ. Wearable devices, Wearables). Такі пристрої для носіння можуть бути для загального використання, і в цьому випадку вони $\epsilon$ лише особливо малим прикладом мобільних комп'ютерів. В якості альтернативи вони можуть бути призначені для спеціальних цілей, таких як фітнес-трекери або медичні пристрої. Вони можуть включати спеціальні датчики та сенсори, такі як акселерометри, монітори серцевого ритму, або більш просунуті, електрокардіограма, монітори насичення крові киснем та датчики контролю артеріального тиску;

- Біологічний зворотний зв'язок (БЗЗ, англ. Biofeedback). Технології Б33 [3], включають в себе комплекс дослідницьких, немедичних, фізіологічних, профілактичних і лікувальних процедур, в ході яких людині за допомогою зовнішньої ланцюга зворотного зв'язку, організованого переважно за допомогою мікропроцесорної або комп'ютерної техніки, пред'являється інформація про стан і зміни тих чи інших власних фізіологічних процесів. Б3Зпроцедура полягає в безперервному моніторингу в режимі реального часу певних фізіологічних показників i свідоме управління ними за допомогою мультимедійних, ігрових та інших прийомів в заданій області значень. Таким чином протягом курсу БЗ3-сеансів можливо посилити або послабити даний фізіологічний показник, а отже, рівень тонічної активації тієї регуляторної системи, чию активність даний показник відображає.

Інтелектуальні/Віртуальні особисті помічники (англ. Intelligent/Virtual personal assistant). Це програмні агенти, що можуть надавати персональну інформацію, виконувати завдання та послуги для окремої особи. Сучасні програмні агенти класу інтелектуальних/віртуальних особистих помічників можуть взаємодіяти між собою задля виконання певного класу завдань. Взаємодія 3 такими помічниками з боку людини зазвичай відбувається за допомогою голосу або тексту. Іноді стосовно віртуальних помічників 3 текстовим інтерфейсом застосовують термін "чатбот". Зокрема, в рамках проєкту та системи TISP розроблено універсальну діалогову підсистему [12] (імплементовано в рамках предметної галузі "Фізична і реабілітаційна медицина" ФРМ) у формах веб-застосунку та віртуального співрозмовника у сервісі “Telegram”. Розроблена діалогова підсистема TISP використовує елементи онтологічного інжинірингу, зокрема, онтологічне представлення "Білої книги 3 фізичної та реабілітаційної медицини в Свропі" (БК, англ. The White Book of Physical and Rehabilitation Medicine in Europe) [13] та Міжнародну класифікацію функціонування, обмеження життєдіяльності та здоров'я (МКФ, англ. International Classification of Functioning, Disability and Health, ICF) [14].

- Методи, технології та програмні застосунки на основі штучного інтелекту для обробки великих даних (англ. Big data) з метою вилучення знань та вирішення аналітичних завдань [15]. Для виявлення та видобування знань та вирішення основних аналітичних завдань, таких як класифікація, діагностика чи прогнозування, ми використовуємо метод під назвою "Зростаючі пірамідальні мережі" [15] (ЗПМ, англ. Growing pyramidal networks, $G P N)$. Результатом навчання є закономірність у вигляді логічної функції (функції алгебри логік). ЗПМ належить до класу статистичних методів. Інтелектуальний інформаційний пошук також базується на використанні прогностичних моделей дистрибутивної семантики [9].

Типовим представником систем, що 
реалізують концепцію гібридної Е-реабілітації $\epsilon$ Трансдисциплінарна інтелектуальна інформаційноаналітична система супроводження процесів реабілітації при пандемії (TISP) та, зокрема, ¥іі пацієнт-центрична інформаційна підсистема Smart-система телемедичного супроводження реабілітаційних заходів.

Розглянемо розроблену загальну інформачійну модель Smart-системителемедичного супроводження реабілітаційних заходів. Узагальнена інформаційна модель Smart-системи телемедичного супроводження реабілітаційних заходів представляється у вигляді трикомпонентного кортежу $S$ з використанням формалізму наведеного в [6]:

$$
S=\langle D, F, E\rangle,
$$

де:

$S$ - Smart-система телемедичного супроводження реабілітаційних заходів (підсистема TISP).

$D$ - множина програмних засобів у вигляді вебсервісів (Інтернет-застосунків) та десктопних сервісів (комп'ютерних програм), доступних для використання в Smart-системі телемедичного супроводження реабілітаційних заходів:

$$
D=\sum_{j=1}^{k} Z_{T_{j}}
$$

де: $Z_{T_{j}}$ - програмний засіб, що здійснює та функцій Smart-системи телемедичного супроводження реабілітаційних заходів

$$
S j=\overline{1, k}, k \in \mathbb{N}, k \text { ( - кількість розроблених }
$$
входять до складу Smart-системи телемедичного супроводження реабілітаційних заходів).

$$
F=S:\left\{C_{i} \mid i=\overline{1, n}\right\}_{n \in \mathbb{N}} \underset{\text { кожна фножина функцій, }}{- \text { фунція } \epsilon}
$$

результатом координування та взаємодії елементів $S$;

$$
C_{i} \subseteq D, C_{i}=\left\{D_{y} \mid y \geq 1, y \leq m\right\}_{y \in \mathbb{N}, m \in \mathbb{N}} \text { підмножина }
$$

програмних засобів, що необхідна для реалізації $i$-ої функції Smart-системі телемедичного

супроводження реабілітаційних заходів $S$. Формування цієї підмножини дозволяє вибудовувати персоніфіковані пайплайни та сценарії використання розроблених програмних засобів (а також використання додаткового зовнішнього програмного забезпечення), що дозволяє лікарю ФРМ більш гнучке використання сервісів Smart-системи телемедичного супроводження реабілітаційних заходів. Формування таких пайплайнів і сценаріїв виходить за рамки даної статті та повинно розглядатися окремо.
На теперішньому етапі розробки, Smart-система телемедичного супроводження реабілітаційних заходів включає до себе різноманітні технології, сервіси та інструменти, зокрема:

$$
\sum_{j=1}^{6} Z_{T_{j}}=\left\{T_{1}, T_{2}, T_{3}, T_{4}, T_{5}, T_{6}\right\},
$$

$T_{1}$ - сервіс телемедичного консультування відеомодуль Smart-системі телемедичного супроводження реабілітаційних заходів (забезпечує онлайн відео або аудіо спілкування) 3 використанням програмного забезпечення з відкритим початковим кодом Jitsi Meet.

$T_{2}$ - сервіс "Цифровий кабінет лікаря спеціалізованої медичної допомоги, зокрема, лікаря фізичної та реабілітаційної медицини. В особистому “електронному кабінеті" знаходяться інструменти для ведення онлайн прийому, в тому числі, для відео-консультацій, особистий профіль лікаря та пацієнтів, управління фінансами, календар для складання графіка та планування консультацій, доступ до бази пацієнтів лікаря, модуль складання електронних консультативних висновків за підсумками відео-консультації;

$T_{3}$ - сервіс автоматизованої обробки та інтеграції базових робочих процесів медичної установи для взаємодії адміністратора, лікаря та пацієнта.

$T_{4}$ - сервіс колективної взаємодії, для створення т а використання служб файлообміну, зокрема забезпечення передачі медичних цифрових зображень DICOM (англ. Digital Imaging and Communications in Medicine, Цифрова обробка зображень та комунікаиї в медицині - універсальний формат для зберігання та перенесення зображень: рентгенографії; комп'ютерної томографії; магнітно-резонансної томографії; ультразвукової діагностики, що $\epsilon$ галузевим стандартом у медицині) через комп'ютерну мережу з використанням програмного забезпечення 3 відкритим початковим кодом Nextcloud [16].

$T_{5}$ - сервіс UkrVectōrēs [17] - електронний засіб для дослідження, моделювання та вивчення довільних предметних галузей, “когнітивносемантичний калькулятор”, що працює на основі технологій комп'ютерного аналізу та розуміння природної мови (елементи штучного інтелекту), для виявлення, класифікації, діагностики та прогнозування знань.

$T_{6}$ - сервіс “Електронна бібліотека vHealth" розподілена інформаційна система, що дозволяє зберігати, використовувати та розповсюджувати різнорідні колекції електронних документів (відео- та аудіо- контент) довільних предметних галузей, для дистанційного навчання пацієнтів i їх родичів, зокрема, реабілітаційному комплексу вправ та заходів.

Результати. Детально розглянемо деякі програмні засоби розроблені згідно узагальненої інформаційної модель Smart-системи телемедичного супроводження 
реабілітаційних заходів, зокрема:

- сервіс UkrVectōrēs - електронний засіб для дослідження, моделювання та вивчення довільних предметних галузей, “когнітивно-семантичний калькулятор”, що працює на основі технологій комп'ютерного аналізу та розуміння природної мови, для виявлення, класифікації, діагностики та прогнозування знань;

- сервіс Електронна бібліотека vHealth розподілена інформаційна система, що дозволяє зберігати, використовувати та розповсюджувати різнорідні колекції електронних документів (відео, аудіо) довільних предметних галузей, для дистанційного навчання пацієнтів i їх родичів, зокрема, реабілітаційному комплексу вправ та заходів.

Cервic UkrVectōrēs. Мережевий засіб UkrVectōrēs обчислює семантичні відношення між сутностями української мови в рамках обраної дистрибутивно-семантичної моделі векторного представлення сутностей. UkrVectōrēs - це інструмент дистрибутивного аналізу природної мови, метод дослідження природної мови, заснований на вивченні середовища (дистрибуції, розподілу), окремих сутностей у тексті без повного лексичного або граматичного значень цих сутностей. В загальному випадку дистрибутивний аналіз [9] використовує, базується та досліджує сутності природної мови, такі як слова або словосполучення. В рамках даного методу до текстів природною мовою застосовується впорядкований набір універсальних процедур, що дозволяє виділити основні одиниці мови (фонеми, морфеми, слова, словосполучення), провести ï класифікацію та встановити відношення семантичної схожості між ними.

Мережевий засіб UkrVectōrēs - це інструмент, який дозволяє досліджувати семантичні відношення між словами в рамках прогностичних моделей дистрибутивної семантики, 3 використанням програмної бібліотеки з відкритим вихідним кодом для обробки та математичного моделювання природної мови gensim [18] (яка включає інтерфейс прикладного програмування для роботи 3 алгоритмами Word $2 \mathrm{vec}$, fastText та інші). Користувач може вибрати одну або кілька 3 ретельно підготовлених прогностичних моделей дистрибутивної семантики (або використати свою модель векторного представлення для слів української мови), навчених на різних корпусах текстів, зокрема, такого набору даних (англ. Dataset), як БК [13]. Мережевий засіб UkrVectōrēs охоплює наступні елементи дистрибутивносемантичного аналізу:

- обчислення семантичної схожості/близькості між парами слів в рамках обраної прогностичної моделі дистрибутивної семантики;

- знаходження слова, найближчого до заданого в рамках обраної прогностичної моделі дистрибутивної семантики (обчислення семантичних асоціатів). Коефіцієнт косинусної близькості слів може приймати значення в проміжку $\left[\begin{array}{lll}-1 & \ldots & 1\end{array}\right]$. Якщо коефіцієнт косинусної схожості/близькості сутностей - слів приймає значення в проміжку $[-1 \ldots 0,5]$ - це свідчить про відсутність схожих контекстів в наборі даних та найменшу семантичну близькість слів. Якщо коефіцієнт косинусної схожості/близькості сутностей - слів приймає значення в проміжку [0,5 ... 1] - це свідчить про наявність схожих контекстів в наборі даних та більшу семантичну близькість слів. Чим більше коефіцієнтом косинусної схожості/близькості наближається до 1, тим більша семантична близькість слів та більше схожих контекстів в наборі даних;

- виконання над векторами слів алгебраїчних операцій в рамках обраної прогностичної моделі дистрибутивної семантики;

- генерування семантичної карти (з використанням програмного інструментарію 3 відкритим початковим кодом TensorFlow [19]) відношень між словами (це дозволяє виявляти семантичні кластери або тестувати гіпотези на таких кластерах);

- використання інших прогностичних моделей дистрибутивної семантики, які вільно поширюються.

Розглянемо методику роботи користувача 3 графічним інтерфейсом односторінкового застосунку UkrVectōrēs, зокрема, для дистрибутивносемантичного аналізу текстів природної мови.

Обчислення семантичних асоиіатів для заданого слова в рамках обраної дистрибутивно-семантичної моделі. Для використання цієї функції необхідно:

1. Запустити графічний інтерфейс односторінкового застосунку UkrVectōrēs. Для цього в адресному рядку веб-браузера потрібно вписати наступне посилання: https://ukrvectores.e-library.ml та в головному меню обрати режим роботи "Семантичні асоціати";

2. За допомогою випадаючого списку компонента select під назвою "Моделі" обрати бажану дистрибутивно-семантичну модель, в рамках якої буде проводитися обчислення семантичних асоціатів (в загальному випадку, за замовчуванням, використовується нейронна векторна модель представлення слів «Біла книга» (з використанням набору даних - БК), алгоритм word2vec 500d.

3. В полі компоненту intput під назвою "Введіть лему слова" вкажіть бажану лему слова, до якого треба обчислити семантичні асоціати;

4. На екрані відобразяться семантичні асоціати для заданої леми слова "реабілітація" в рамках обраної дистрибутивно-семантичної моделі "Біла книга";

5. Використовуючи елемент "Косинусна близькість" користувач може обрати відображення семантичних асоціатів за коефіцієнтом косинусної схожості/близькості (за збільшенням або за зменшенням). 
Генерування семантичних карт (з використанням програмного інструментарію з відкритим початковим кодом TensorFlow [19]) відношень між словами в рамках обраної дистрибутивно-семантичної моделі. Для використання цієї функції необхідно:

1. Запустити графічний інтерфейс односторінкового застосунку UkrVectōrēs та в головному меню обрати режим роботи "Семантична карта";

2. За допомогою випадаючого списку компонента select під назвою "Моделі" обрати бажану дистрибутивно-семантичну модель, в рамках якої буде проводитися обчислення центра лексичного кластера (в загальному випадку, за замовчуванням, використовується нейронна векторна модель представлення слів “Біла книга").

Технологія компіляції, збірки, розгортання та більш детальний опис початкового коду мережевого засобу UkrVectōrēs, а також методика тренування дистрибутивно-семантичної моделі векторного представлення сутностей (з використанням набору даних - БК) виходять за рамки даної статті. На теперішній час, актуальна версія сервісу UkrVectōrēs доступна за посиланням https://ukrvectores.e-library. $\mathrm{ml}$ та вільна для використання в науково-дослідних та педагогічних цілях.

Cepвic vHealth. Електронна бібліотека медіафайлів підсистеми телереабілітації TISP - сервіс vHealth [20] - це розподілена інформаційна система, що дозволяє зберігати, використовувати та розповсюджувати (функція шерингу) різнорідні колекції електронних документів (відео та аудіо контент) довільних предметних галузей, для дистанційного навчання пацієнтів і їх родичів, зокрема, реабілітаційному комплексу вправ та заходів. Одним із основних завдань та призначень сервісу vHealth $\epsilon$ інтеграція інформаційних ресурсів і ефективна навігація в них. Інтеграція інформаційних ресурсів - це їхнє об'єднання 3 метою використання різної інформації зі збереженням іiї властивостей, особливостей представлення і можливостей іï обробляти. Для вирішення цієї задачі, сервіс vHealth використовує інтелектуальний пошук на основі прогностичних моделей дистрибутивної семантики.

Сервіс “Електронна бібліотека vHealth" має наступні функціональні можливості:

- підтримка декількох робочих процесів публікації контенту (режиму доступу): загальнодоступний контент, приватний контент, контент, що не входить до жодного списку та доступний тільки за посиланням;

- підтримка декількох медіа-форматів (медіатипів) даних: аудіо контент, відео контент та підтримка текстових документів pdf, docx;

- обмін медіа-контентом 3 використанням спільного доступу до окремих медіа-ресурсів, списків відтворення (плейлистів), категорій, тегів. Автоматична генерація коду для вставки медіаконтенту на зовнішній Web-pecypc;
- інтелектуальний інформаційний пошук в реальному часі на основі прогностичних моделей дистрибутивної семантики;

- функція формування списків відтворення (плейлистів) медіа-контенту із налаштуванням робочих процесів публікації контенту (режиму доступу);

- функція розширеного адміністрування користувачами 3 використанням окремої панелі адміністратора сервісу.

Розглянемо методику роботи користувача 3 графічним інтерфейсом односторінкового застосунку vHealth.

За основу побудови графічного інтерфейсу користувача мережевого засобу vHealth було взято інтерфейс популярної медіа-платформи Youtube, який $\epsilon$ еталоном для систем розповсюдження медіа-контенту. Це значно полегшує взаємодію користувача 3 системою та не потребує розробки додаткових методик та настанов користувача для взаємодії з графічним інтерфейсом програмної системи.

Розглянемо основні елементи графічного інтерфейсу користувача мережевого засобу vHealth (рис. 2):

- центральна частина інтерфейсу містить весь медіа-контент доступний для користувача відповідно до його профілю. Медіа-контент (за замовчуванням) розподілено за категоріями;

- частина інтерфейсу зліва містить пункти головного меню мережевого засобу vHealth, зокрема, пункти: “Завантажити” (функція завантаження нового медіа-контенту); "Мої файли" (функція перегляду завантаженого медіаконтенту в профілі користувача); "Мої плейлисти" (формування списків відтворення - плейлистів медіа-контенту із налаштуванням робочих процесів публікації контенту); “Історія” (функція перегляду списку медіа-контенту, що було вже переглянуто); "Персонал" (функція перегляду всіх користувачів cервicy vHealth); "Категоріï” та "Теги” (функція каталогізації об'єктів медіа-контенту та різних їхніх об'єднань).

- графічний інтерфейс профілю користувача наведено на рисунку 2. Користувач має доступ до персонального медіа-контенту та має змогу редагувати графічний інтерфейс свого профілю та кожен об'єкт медіа-контенту. Також є доступ до сторінки із списками відтворення (плейлистами) користувача.

Технологія компіляції, збірки, розгортання та більш детальний опис методики роботи користувача з графічним інтерфейсом застосунку vHealth потребують окремого розгляду. На теперішній час, актуальна версія сервісу vHealth доступна за посиланням: https://e-library. ml/. Для початку роботи 3 сервісом vHealth необхідно бути авторизованим користувачем. Авторизуватися можна використавши логін та 
пароль облікового запису демонстраційного профілю: Ім'я користувача - demouser; пароль JyMyuC6nMdD494T.

Обговорення. Першочергові виклики постали перед системою медичної реабілітації в Україні. До особливо важливих завдань відноситься, у першу чергу, реабілітація хворих, які одужали від COVID-19. Цей факт добре усвідомлюється, як суспільством, так i керівництвом MO3 України, яке наразі створює спеціальну робочу групу 3 цієї проблеми. Україна має систему лікувально-профілактичних закладів, призначених для психологічної та фізичної реабілітації військовослужбовців, в яких використовуються сучаснітехнологіїреабілітації. Однак, довготривала реабілітація в таких центрах доступна далеко не всім. Тому, застосування технології телереабілітації хворих з посттравматичним стресовим розладом та подібними розладами, в поєднанні з засобами об'єктивного контролю функціонального стану є вкрай важливим.

Роботи виконуються за проектом НФДУ, який має назву “Трансдисциплінарна інтелектуальна інформаційно-аналітична система супроводження процесів реабілітації при пандемії (TISP)". Особливістю системи є те, що вона базується на знання-орієнтованій технології, онтологічному інжинірингу i трансдисциплінарній парадигмі. Когнітивні сервіси системи реалізують структуризацію і класифікацію інформації, синтезують необхідні документи на основі семантичного аналізу, виявляють характерні властивості інформаційних процесів і забезпечують підтримку прийняття рішень на всіх етапах їх життєвого циклу.

\section{Результати і Висновки:}

1. Визначено поняття Гібридна Е-реабілітація та його фундаментальні основи.

2. Розроблено формальну інформаційну модель Smart-системи телемедичного супроводження реабілітаційних заходів.

3. Розроблено програмну реалізацію сервісів Smart-системи телемедичного супроводження реабілітаційних заходів, зокрема, електронної бібліотеки медіа-файлів підсистеми телереабілітації TISP - сервіс vHealth та електронного засобу для дослідження, моделювання та вивчення довільних предметних галузей - сервіс UkrVectōrēs.

4. Наведені методологічні основи застосування сервісів дистанційної пацієнт-центричної Smartсистеми надання медичної реабілітаційної допомоги пацієнтам при пандемії, зокрема, нової коронавірусної хвороби COVID-19.

Перспективи подальших досліджень. У подальшій роботі планується впровадження в практику комп'ютерних програм для оптимізації затрат часу фахівцями мультидисциплінарної команди при застосуванні МКФ в реабілітації онкологічних хворих (зокрема, на рак молочної залози). Також плануються подальші дослідження в визначенні та застосуванні ефективних математичних методів аналізу великих об'ємів даних, моделювання і побудови сценаріїв прогнозування, і оптимізації усього комплексу реабілітаційних процедур i їх маршрутизації з використанням вже апробованих в колективі системних засобів, технологій та досвіду

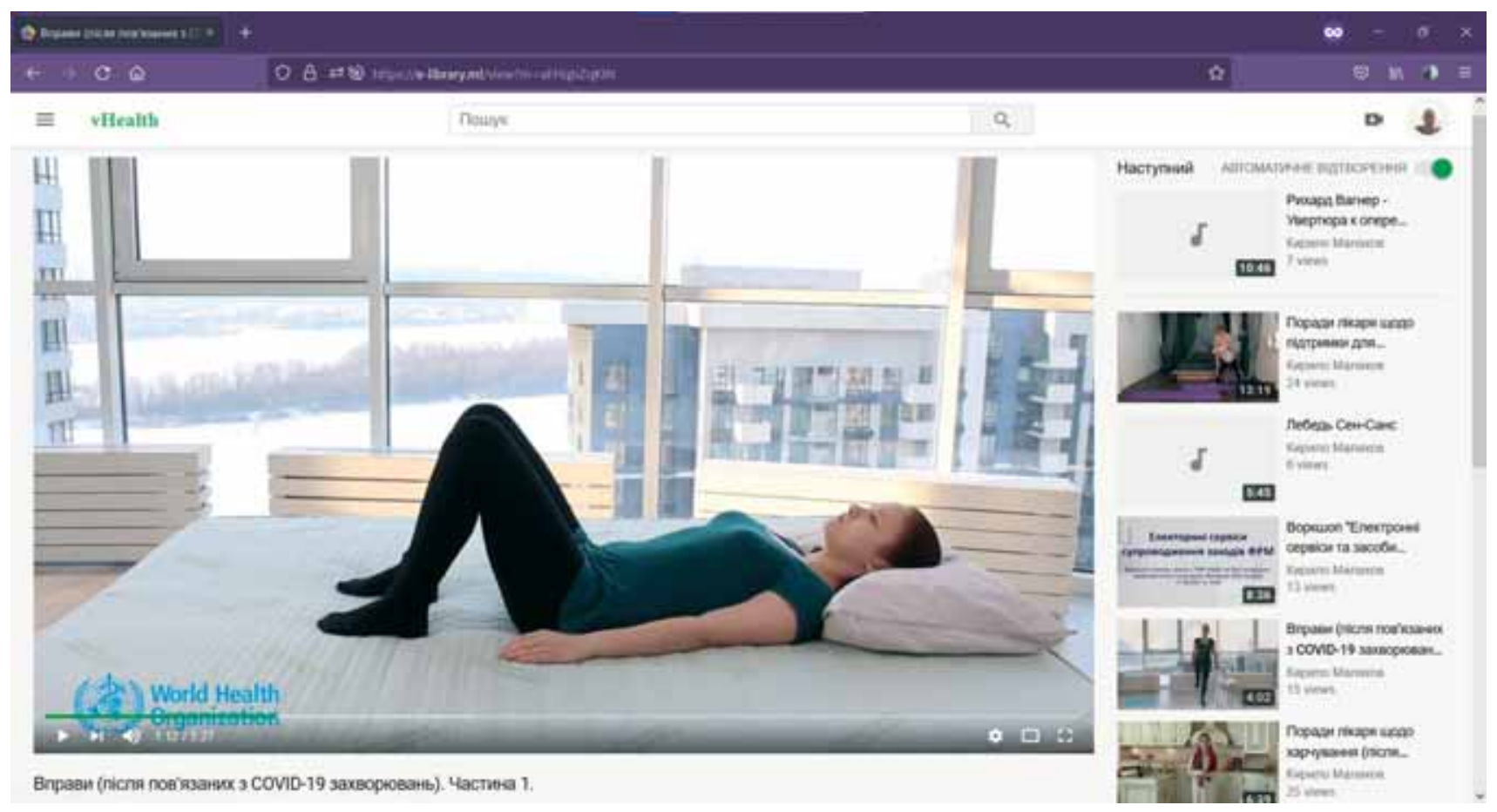

Рисунок. 2. Графічний інтерфейс користувача мережевого засобу vHealth (Сторінка профілю користувача). 
розробки реабілітаційних комплексів.

Додаткова інформація. Опубліковані матеріали на мають конфлікту інтересів.

\section{Подяки.}

Дослідження виконано при підтримці гранту НФДУ за договором від 07.05.2021 р. № 159/01/0245 “Трансдисциплінарна інтелектуальна інформаційноаналітична система супроводження процесів реабілітації при пандемії (TISP)" та на базі Інституту кібернетики ім. В.М. Глушкова Національної академії наук України, м. Київ, Україна.

\section{Список літератури}

1. Трансдисциплінарна інтелектуальна інформацій-ноаналітична система супроводження процесів реабілітації при пандемії TISP. Монографія. За редакцією Палагіна О.В.Просвіта,Київ, Україна;ITHЕАСофія,Болгарія. 2021. DOI: https://doi.org/10.54521/ibs34.

2. Національний фонд досліджень України. URL: https:// nrfu.org.ua/. (Дата звернення: 24.10.2021).

3. Palagin O, Kurgaev A. 2021. Rehabilitation According to the Biological Feedback. 2021 IEEE 11th International Conference on Intelligent Data Acquisition and Advanced Computing Systems: Technology and Applications. Cracow University of Technology. Cracow, Poland September 2225, 2021. DOI: https://doi.org/10.5281/zenodo.5635711.

4. Палагін О.В., Семікопна Т.В., Чайковський І.А., Сивак O.В. Телереабілітація: інформаційно-технологічна підтримка та досвід використання. Клінічна інформатика і Телемедицина, 2020, Том 15, Випуск 16, C. 35-44. DOI: https://doi.org/10.31071/kit2020.16.15.

5. Palagin A.V., Petrenko N.G., Velychko V.YU. and Malakhov K.S. (2014) Development of formal models, algorithms, procedures, engineering and functioning of the software system "Instrumental complex for ontological engineering purpose". In:Proceedings of the 9th International Conference of Programming UkrPROG. CEUR Workshop Proceedings 1843. Kyiv, Ukraine, May 20-22, 2014. URL: http://ceur-ws.org/Vol-1843/221-232.pdf.

6. Palagin O.V., Velychko V.YU., Malakhov K.S., Shchurov O.S. (2018) Research and development workstation environment: the new class of current research information systems. In: Proceedings of the 11 th International Conference of Programming UkrPROG 2018. CEUR Workshop Proceedings 2139. Kyiv, Ukraine, May 22-24, 2018. URL: http://ceur-ws.org/Vol-2139/255-269.pdf.

7. Палагин А.В., Петренко Н.Г., Малахов К.С. Методика проектирования онтологии предметной области. Комп 'ютерні засоби, мережі та системи. 2011. № 10. C. 5-12. URL: http://www.dasd.com.ua/kzms/2011/2011 st1.pdf.

8. Величко В.Ю., Малахов К.С., Семенков В.В., Стрижак А.Е. Комплексные инструментальные средства инженерии онтологий. Information Models and Analyses. 2014. Випуск 3, № 4. С. 336-361. URL: http://www.foibg. com/ijima/vol03/ijima03-04.pdf\#page=36.

9. Palagin O.V., Velychko V.YU., Malakhov K.S., Shchurov O.S. (2020) Distributional semantic modeling: a revised technique to train term/word vector space models applying the ontology-related approach. In: Proceedings of the 12th International Conference of Programming UkrPROG 2020. CEUR Workshop Proceedings 2866. Kyiv, Ukraine, September 15-16, 2020. URL: http://ceur-ws.org/Vol-2866/ ceur 342-352palagin34.pdf.

10. Palagin O, Velychko V, Malakhov K. 2021. An AI-based approach for decision-making in Hybrid E-rehabilitation. Oral Presentation. 2021 IEEE 11th International Conference on Intelligent Data Acquisition and Advanced Computing Systems: Technology and Applications. Cracow University of Technology. Cracow, Poland, September 22-25, 2021. DOI: https://doi.org/10.5281/zenodo.5635645.

11. Електронна система охорони здоров'я в Україні. URL https://ehealth.gov.ua/.

12. Litvin, A.A., Velychko, V.Y., \& Kaverynskyi, V.V. (2021). Tree-based semantic analysis method for natural language phrase to formal query conversion. Radio Electronics, Computer Science, Control, (2), 105-113. DOI: https://doi.org/10.15588/1607-3274-2021-2-11.

13. White Book on Physical and Rehabilitation Medicine in Europe URL: http://www.whitebookprm.eu/.

14. International Classification of Functioning, Disability and Health (ICF). URL: https://www.who.int/classifications/internationalclassification-of-functioning-disability-and-health.

15. Gladun V., Velychko V., Ivaskiv Y. Selfstructurized Systems. Information Theories \& Applications. 2008, № 1. P. $5-13$.

16. Nextcloud: набір клієнт-серверного програмного забезпечення для створення та використання служб файлообміну. URL: https://github.com/nextcloud.

17. UkrVectōrēs - An NLU-Powered tool for knowledge discovery, classification, diagnostics and prediction. URL:https://github.com/malakhovks/docsim. DOI: https://doi.org/10.5281/zenodo.5632231.

18. Genism Topic modelling for humans. Radimrehurek website. URL: https://radimrehurek.com/gensim/.

19. TensorFlow. (2021). TensorFlow website. URL: https:// www.tensorflow.org/tutorials/text/word2vec.

20. vHealth - Електронна бібліотека медіа-файлів підсистеми телереабілітації TISP. URL: https://e-library. $\underline{\mathrm{ml}}$.

\section{References}

1. Transdisciplinary intelligent information and analytical system for the rehabilitation processes support in a pandemic. Monograph. Edited by Palagin OV. Prosvita, Kyiv, Ukraine; ITHEA Sofia, Bulgaria. 2021 (in Ukrainian) DOI: https://doi.org/10.54521/ibs34.

2. National research foundation of Ukraine. Available from: https://nrfu.org.ua/. Accessed: October 24, 2021.

3. Palagin O, Kurgaev A. 2021. Rehabilitation According to the Biological Feedback. 2021 IEEE 11th International Conference on Intelligent Data Acquisition and Advanced Computing Systems: Technology and Applications. Cracow University of Technology. Cracow, Poland September 22- 
25, 2021. DOI: https://doi.org/10.5281/zenodo.5635711.

4. Palagin A, Semikopnaya T, Chaikovsky I, Sivak O. Telerehabilitation: information and technological support, experience of application. Klin. inform. telemed., 2020, vol. 15, iss. 16, pp. 35-44. DOI: https://doi.org/10.31071/ kit2020.16.15.

5. Palagin A.V., Petrenko N.G., Velychko V.YU. and Malakhov K.S. (2014) Development of formal models, algorithms, procedures, engineering and functioning of the software system "Instrumental complex for ontological engineering purpose". In:Proceedings of the 9thInternational Conference of Programming UkrPROG. CEUR Workshop Proceedings 1843. Kyiv, Ukraine, May 20-22, 2014. Available from: http://ceur-ws.org/Vol-1843/221-232.pdf. Accessed: October 24, 2021.

6. Palagin O.V., Velychko V.YU., Malakhov K.S., Shchurov O.S. (2018) Research and development workstation environment: the new class of current research information systems. In: Proceedings of the 11th International Conference of Programming UkrPROG 2018. CEUR Workshop Proceedings 2139. Kyiv, Ukraine, May 22-24, 2018. Available from: http://ceur-ws.org/Vol-2139/255-269.pdf. Accessed: October 24, 2021.

7. Palagin A.V., Petrenko N.G., Malakhov K.S. Technique for designing a domain ontology. Computer means, networks and systems. 2011. N 10. P. 5-12. (In Russian). Available from: http://www.dasd.com.ua/kzms/2011/2011 st1.pdf. Accessed: October 24, 2021.

8. Velychko V.YU., Malakhov K.S., Semenkov V.V., Strizhak A.E. Integrated Tools for Engineering Ontologies. Information Models and Analyses. 2014. N 4. P. 336361. Avaliable from: http://www.foibg.com/ijima/vol03/ ijima03-04.pdf\#page=36. Accessed: October 24, 2021. (In Russian).

9. Palagin O.V., Velychko V.YU., Malakhov K.S., Shchurov O.S. (2020) Distributional semantic modeling: a revised technique to train term/word vector space models applying the ontology-related approach. In: Proceedings of the 12th International Conference of Programming UkrPROG 2020. CEUR Workshop Proceedings 2866. Kyiv, Ukraine, September 15-16, 2020. Available from: http://ceur-ws.org/Vol-2866/ceur_342-352palagin34.pdf. Accessed: October 24, 2021.

10. Palagin O, Velychko V, Malakhov K. 2021. An AI-based approach for decision-making in Hybrid E-rehabilitation.
Oral Presentation. 2021 IEEE 11th International Conference on Intelligent Data Acquisition and Advanced Computing Systems: Technology and Applications. Cracow University of Technology. Cracow, Poland, September 22-25, 2021. DOI: https://doi.org/10.5281/zenodo.5635645.

11. Electronic health care system in Ukraine. Available from: https://ehealth.gov.ua/. Accessed: October 24, 2021.

12. Litvin, A.A., Velychko, V.Y., \& Kaverynskyi, V.V. (2021). Tree-based semantic analysis method for natural language phrase to formal query conversion. Radio Electronics, Computer Science, Control, (2), 105-113. DOI: https://doi.org/10.15588/1607-3274-2021-2-11.

13. White Book on Physical and Rehabilitation Medicine in Europe. Available from: http://www.whitebookprm.eu/. Accessed: October 24, 2021.

14. International Classification of Functioning, Disability and Health (ICF). Available from: https://www.who.int/classifications/ international-classification-of-functioning-disability-andhealth. Accessed: October 24, 2021.

15. Gladun V., Velychko V., Ivaskiv Y. Selfstructurized Systems. Information Theories \& Applications. 2008, № 1. P. $5-13$.

16. Nextcloud: eA safe home for all your data - community-driven, free \& open source. Available from: https://github.com/nextcloud. Accessed: October 24, 2021.

17. UkrVectōrēs - An NLU-Powered tool for knowledge discovery, classification, diagnostics and prediction. Available from: https://github.com/malakhovks/docsim. Accessed: October 24, 2021. DOI: https://doi.org/10.5281/ zenodo.5632231.

18. Genism Topic modelling for humans. Radimrehurek website. Available from: https://radimrehurek.com/gensim/. Accessed: October 24, 2021.

19. TensorFlow. (2021). TensorFlow website. Available from: https://www.tensorflow.org/tutorials/text/word2vec. Accessed: October 24, 2021.

20. vHealth - modern web platform for viewing and sharing media (streaming video training service, for distance learning of patients, in particular, a rehabilitation complex of exercises). Available from: https://e-library.ml/. Accessed: October 24, 2021.

\title{
SMART-SYSTEM FOR REMOTE SUPPORT OF REHABILITATION ACTIVITIES AND SERVICES: FORMAL MODEL AND APPLICATIONS DEVELOPMENT
}

\author{
Velychko V.Yu., Malakhov K.S., Shchurov O.S., Semykopna T.V., Palagin O.V.
}

\begin{abstract}
The methodology of rehabilitation measures in a pandemic has several significant features associated with the unpredictability and high rate of emergence of problems of high complexity, limited communication between the therapist and the patient, the need for high responsiveness of decision-making and their compliance, the scale of the process and the associated need to use scalable operating tools, etc. One of the most effective solutions in medical rehabilitation assistance is remote patient/personal-centered rehabilitation. It requires online telediagnostic tools, telemetry and interventions focused on the patient's capabilities, developed Internet interaction, intelligent information technologies, and services. Patient/personal-centered rehabilitation also needs effective methods in the "Physical therapist
\end{abstract}


- Patient - Multidisciplinary team" system, statistical processing of large volumes of data, etc. Therefore, along with the traditional means of rehabilitation, as part of the "Transdisciplinary intelligent information and analytical system for the rehabilitation processes support in a pandemic (TISP)" the Smart-system for remote support of rehabilitation activities and services appeared. Combined with intelligent remote biofeedback devices and effective miniature telediagnostics, telemetry and recovery devices, such systems hold great promise, as evidenced by world experience as well. Objective of the research was to develop a formal model, software implementation, and methodological foundations for the use of services of a remote patient/personal-centered Smart-system for providing medical rehabilitation assistance to patients in a pandemic, in particular, the new coronavirus disease COVID-19. The world modern and generally accepted definition of the concept of Telerehabilitation or E-rehabilitation is a complex of rehabilitation exercises and training programs that are provided to the patient remotely using telecommunication computer technologies, mainly at the outpatient stage of treatment. The rapid development of telerehabilitation in the world and the acquisition by this direction of medicine of transdisciplinary connections with various subject areas that go beyond the modern paradigm of E-health, led to the emergence of the most modern type of rehabilitation - Hybrid E-rehabilitation. This type of E-rehabilitation consists of a number of the following fundamental methods, approaches and technologies: telecommunication technologies, telemetry, embedded systems and miniature smart wearable devices, biofeedback, virtual personal assistants, methods, technologies and software artificial intelligence applications for big data processing.

The formal model, software implementation, and methodological foundations for the use of services (UkrVectōrēs, vHealth) of a remote patient/personal-centered Smart-system for providing medical rehabilitation assistance to patients in a pandemic, in particular, the new coronavirus disease COVID-19, have been developed.

Key words: international classification of functioning, rehabilitation, patient/personal-centered rehabilitation, multi-professional team, digital library, natural language processing, artificial intelligence, intelligent information technology. 